\title{
Penilaian Kepuasan Kerja Karyawan Terhadap Sistem Pengelolaan Sumberdaya Manusia di Rumah Sakit
}

\author{
Ria Chandra Kartika \\ Program Studi Gizi Klinik, Jurusan Kesehatan, Politeknik Negeri Jember, \\ riachandrakartika@polije.ac.id
}

\begin{abstract}
ABSTRAK
Penilaian kepuasan kerja karyawan terhadap system pengelolaan sumberdaya manusia merupakan hal yang penting untuk dilakukan oleh manajemen rumah sakit. Hasil penilaian tersebut dapat digunakan sebagai sumber informasi tentang system pengelolaan sumberdaya di rumah sakit, mengurangi turnover, dan meningkatkan kinerja rumah sakit. Tujuan dari penelitian ini adalah menilai tingkat kepuasan karyawan terhadap system pengelolaan sumberdaya manusia di rumah sakit. Jenis Penelitian ini adalah penelitian observasional dengan rancang bangun crossectional. Populasi pada penelitian ini adalah seluruh karyawan di RSIA NUN Surabaya. Besar sampel pada penellitian ini adalah 45 karyawan yang dipilih menggunakan teknik propotional random sampling. Instrumen yang digunakan dalam penelitian ini adalah MSQ. Hasil penilaian dianalisis secara deskriptif untuk mengetahui nilai kepuasan kerja karyawan. Hasil penelitian menunjukkan bahwa sebesar 66,7\% karyawan memiliki tingkat kepuasan yang berada pada kategori baik. Hal tersebut menunjukkan bahwa sebagian besar pegawai memiliki kepuasan kerja yang baik terkait dengan pengelolaan sumberdaya manusia. Manajemen rumah sakit perlu memperhatikan kepuasan karyawan terkait pencapaian terhadap prestasi kerja, gaji karyawan, dan kondisi lingkungan kerja karena ketiga elemen tersebut memiliki nilai yang lebih rendah dibandingkan dengan elemen yang lain. Sehingga penting bagi rumah sakit untuk mendorong karyawan untuk meningkatkan prestasi kerja dengan memberikan kesempatan karyawan untuk mengembangkan diri melalui kegiatan pendidikan dan pelatihan.Serta melakukan telaah terhadap gaji yang diberikan dan menyediakan lingkungan kerja yang kondusif sehingga dapat meningkatkan kepuasan kerja karyawan.
\end{abstract}

Kata kunci: Kepuasan Kerja Karyawan, Rumah Sakit, Minnesota Satisfication Questionare

\begin{abstract}
Assessment of employee's satisfaction assessment is an important thing to do by the hospital management. The data can be used as a source of information about resource management systems in hospitals, reducing turnover, and improving hospital performance. The objectives of this study was to measure job satisfaction level of the employee at RSIA NUN Surabaya This study is crossectional design study. The sample was 45 employees in RSIA NUN Surabaya were selected using proportional random sampling techniques. The instrument used in this study was MSQ. The assessment results are analyzed descriptively to determine the value of employee job satisfaction. The results of this study showed that $66.7 \%$ of employees had a level of satisfaction that was in the good category. Conclusion of this study hospital management needs to pay attention to employee satisfaction related to the achievement of work performance, employee salaries, and working environment conditions because all three elements have lower values compared to other elements. So it is important for hospitals to encourage employees to improve work performance by giving employees the opportunity to develop themselves through education and training activities. As well as reviewing salaries provided and providing a conducive work environment so as to increase employee job satisfaction.
\end{abstract}

Keywords: Job Satisfaction, Hospital, Minnesota Satisfication Questionare

*Korespondensi Author: Ria Chandra Kartika, Politeknik Negeri Jember, E-mail: riachandrakartika@polije.ac.id,Telp.087755872556

\section{PENDAhULUAN}

Sumber daya manusia merupakan aspek yang berperan sangat penting terhadap keberhasilan suatu pelayanan rumah sakit. Terdapat dua kelompok besar dalam sumber daya manusia di rumah sakit yakni tenaga medis yang terdiri dari dokter, perawat, tenaga kesehatan lain, dan tenaga non-medis yang terdiri dari tenaga administratif serta tenaga pelaksana lainnya. Oleh karena itu rumah sakit 
dituntut untuk mengelola sumber daya manusia yang dimilikinya dengan sangat baik karena salah satu faktor yang menunjukkan keunggulan kompetitif potensial adalah sumber daya manusia dan bagaimana sumber daya tersebut dikelola.

Permasalahan yang sering terjadi dalam pengelolaan sumberdaya manusia di rumah sakit adalah tingginya turnover karyawan. Turnover merupakan pemberhentian pegawai yang bersifat permanen dari perusahaan baik yang dilakukan oleh pegawai sendiri maupun yang dilakukan oleh perusahaan ${ }^{1}$. Dalam organisasi pelayanan kesehatan turnover merupakan tantangan serius terhadap efisiensi dan efektivitas dari setiap sistem pelayanan kesehatan yang dapat memberikan dampak negatif.

Turnover di RSIA NUN Surabaya pada tiga tahun terakhir melebihi standar ideal (5$10 \%$ ) yaitu sebesar 24,2-52,7\%. Tingginya turnover dapat memberikan dampak negatif terhadap organisasi, baik dari segi biaya, sumber daya, maupun motivasi pegawai. Turnover pegawai di suatu organisasi dinpengaruhi oleh keinginan pegawai tersebut untuk meninggalkan organisasi (intention to leave). Intention to leave adalah keinginan berpindah dari pegawai yang mengacu pada kelanjutan hubungannya dengan perusahaan dan belum diwujudkan dalam tindakan pasti meninggalkan perusahaan ${ }^{2}$. Keinginan berpindah (intention to leave) mencerminkan keinginan individu untuk meninggalkan organisasi yang belum dilakukan dalam bentuk tindakan nyata. Setelah pegawai mempunyai keinginan untuk meninggalkan perusahaan dan jika muncul suatu tindakan nyata meninggalkan perusahaan, maka akhirnya terjadilah suatu perputaran pegawai (labour turnover). Faktor yang kemungkinan menyebabkan intention to leave pada karyawan adalah kepuasan kerja karyawan yang rendah terhadap organisasi ${ }^{3}$.

Kepuasan kerja merupakan keadaan emosional yang positif yang merupakan hasil dari evaluasi pengalaman kerja seseorang. Jika kepuasan terhadap organisasi rendah makan karyawan tersebut akan mempengaruhi keinginan mereka untuk keluar dari tempat kerja. Kepuasan kerja adalah sikap yang paling berpengaruh terhadap intention to leave. Hasil studi menunjukkan bahwa kepuasan kerja berkaitan erat dengan proses kognisi menarik diri (pre withdrawal cognition), intensi untuk pergi dan tindakan nyata berupa keputusan untuk keluar dari tempat kerja ${ }^{4}$. Sehingga penting bagi manajemen rumah sakit, untuk menilai kepuasan kerja karyawan.

Kepuasan kerja karyawan merupakan salah satu indikator dalam penilaian akreditasi berdasarkan standar akreditasi SNARS 2018. Dalam bab peningkatan mutu dan keselamatan pasien (PMKP) dijelaskan bahwa indikator kunci untuk mengevaluasi proses, struktur dan outcome yang akan diterapkan di rumah sakit perlu ditetapkan dan mempertimbangkan kepuasan karyawan. Kepuasan karyawan merupakan hal penting yang mempengaruhi produktivitas $^{5}$

Tujuan dari penelitian ini adalah untuk menilai kepuasan kerja terhadap system pengelolaan sumberdaya manusia di rumah sakit. Sehingga manajemen rumah sakit dapat menurunkan angka turnover melalui analisis penilaian kepuasan kerja karyawan.

\section{METODOLOGI}

Penelitian ini merupakan jenis penelitian observasional dengan rancang bangun crossectional.. Tempat penelitian dilakukan di Rumah Sakit Ibu dan Anak (RSIA) NUN Surabaya. Populasi pada penelitian ini adalah seluruh pegawai RSIA NUN Surabaya yang masih aktif bekerja berjumlah 81 orang. Besar sampel pada penelitian adalah 45 orang karyawan yang dipilih menggunakan teknik propotional random sampling.

Pengukuran kepuasan kerja pegawai di RSIA NUN Surabaya dilakukan menggunakan Minnesota Satisfication Questionare (MSQ) yang dibuat oleh Weiss et al pada tahun 1997 yang terdiri dari kepuasan intrinsik, kepuasan ekstrinsik, dan kepuasan umum. Selanjutnya data hasil penelitian tersebut dilakukan analisis 
deskriptif untuk mengetahui kepuasan kerja karyawan.

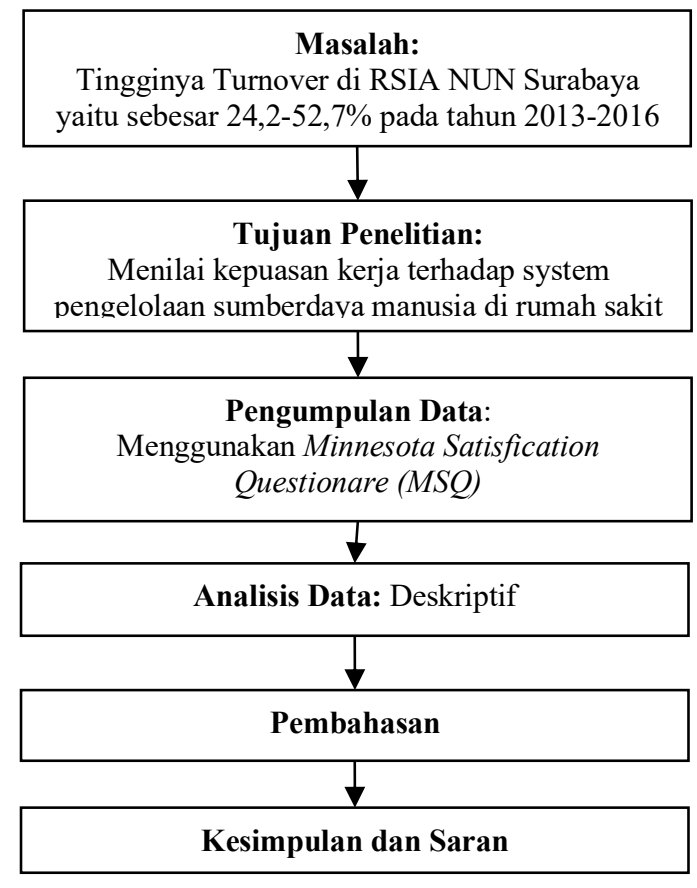

Gambar 1. Bagan Alur Penelitian

\section{HASIL DAN PEMBAHASAN}

Kepuasan kerja atau job satisfaction adalah keadaan emosional yang menyenangkan atau tidak menyenangkan dengan mana para pegawai memandang pekerjaannya ${ }^{6}$ Kepuasan kerja merupakan keadaan emosional yang positif yang merupakan hasil dari evaluasi pengalaman kerja seseorang ${ }^{3}$. Kepuasan kerja dapat didefinisikan sebagai perasaan positif terhadap pekerjaan mereka yang dihasilkan dari evaluasi karakteristik ${ }^{7}$ Berdasarkan beberapa definisi yang telah diuraikan, dapat disimpulkan bahwa kepuasan kerja adalah perasaan senang atau tidak senang pegawai atas segala sesuatu yang dihadapi di tempat kerja pada masing-masing individu. Semakin banyak aspek dalam pekerjaan yang sesuai dengan keinginan individu tersebut, maka semakin tinggi tingkat kepuasan yang dirasakan, demikian juga sebaliknya.

Kepuasan kerja yang digunakan pada penelitian ini diidentifikasi berdasarkan tiga aspek yaitu kepuasan intrinsik, kepuasan ekstrinsik, dan kepuasan umum. Hasil penelitian tentang penilaian kepuasan kerja karyawan pada system pengelolaan sumberdaya manusia di RSIA NUN Surabaya akan dijelaskan pada tabel berikut:

Tabel 1. Hasil Penilaian Kepuasan Kerja Karyawan di RSIA NUN Surabaya

\begin{tabular}{lcccccc}
\hline & \multicolumn{2}{c}{$\begin{array}{c}\text { Kepuasan } \\
\text { Kategori }\end{array}$} & \multicolumn{2}{c}{$\begin{array}{c}\text { Kepuasan } \\
\text { Intrinsik }\end{array}$} & \multicolumn{2}{c}{$\begin{array}{c}\text { Ekstrinsik } \\
\text { Umuasan }\end{array}$} \\
\cline { 2 - 7 } Penilaian & $\mathrm{n}$ & $\%$ & $\mathrm{n}$ & $\%$ & $\mathrm{n}$ & $\%$ \\
\hline Buruk & 0 & 0 & 1 & 2,2 & 0 & 0 \\
Baik & 20 & 44,4 & 30 & 66,7 & 18 & 40 \\
Sangat & 25 & 55,6 & 14 & 31,1 & 27 & 60 \\
Baik & & & & & & \\
\hline Total & 45 & 100 & 45 & 100 & 45 & 100 \\
\hline
\end{tabular}

\section{Kepuasan Intrinsik}

Kepuasan intrinsik adalah perasaan senang atau tidak senang yang merupakan hasil dari persepsi pengalaman pegawai selama masa kerjanya terhadap pekerjaannya. Berdasarkan Tabel 1 diketahui bahwa sebagian besar $(55.6 \%)$ pegawai di RSIA NUN Surabaya memiliki kepuasan intrinsik yang sangat baik. Hal tersebut menunjukkan bahwa pegawai di RSIA NUN merasa senang dengan pekerjaan terhadap pekerjaan yang dilakukan. Kepuasan intrinsik karyawan yang berada dalam kategori baik merupakan hal yang baik bagi rumah sakit. Tingginya kepuasan instrinsik merupakan salah satu cara untuk mencegah turnover intention. Kepuasan intrinsik berpengaruh terhadap keinginan karyawan untuk meninggalkan tempat kerja ${ }^{8}$

Penilaian terendah pegawai di RSIA NUN Surabaya tentang kepuasan intrinsik adalah pada pernyataan "pencapaian terhadap prestasi kerja" dengan rerata sebesar 2,82. Hal tersebut menunjukkan bahwa kepuasan karyawan rendah dikarenakan pencapaian prestasi kerja karyawan masih tidak sesuai dengan yang diharapkan. Pencapaian prestasi, pengakuan merupakan salah satu hal yang meningkatkan kepuasan kerja karyawan. Faktor-faktor mencakup: prestasi kerja (achievement), promosi (promotion), pengakuan (recognition), tanggung jawab (responsibility) merupakan salah satu bentuk 
motivasi yang menyangkut kebutuhan psikologis yang berhubungan dengan penghargaan terhadap individu yang secara langsung berkaitan dengan pekerjaannya dan merupakan sumber kepuasan kerja. Semakin tinggi pengakuan terhadap pekerjaan karyawan maka semakin tinggi pula kepuasan kerja karyawan tersebut. ${ }^{9}$

\section{Kepuasan Ekstrinsik}

Kepuasan ekstrinsik adalah perasaan senang atau tidak senang yang merupakan hasil dari persepsi pengalaman pegawai selama masa kerjanya terhadap aspek yang tidak berhubungan langsung dengan karyawan. Penilaian karyawan terkait dengan kepuasan ekstrinsik pegawai di RSIA NUN, sebagian besar pegawai (66.7\%) menyatakan bahwa memiliki kepuasan yang baik. Hal tersebut menunjukkan bahwa sebagian besar pegawai merasa senang terhadap atasan, kebijakan rumah sakit, dan gaji.

Penilaian tertinggi pegawai di RSIA NUN Surabaya tentang kepuasan ekstrinsik adalah pada pernyataan "kesempatan untuk berkembang" dengan rerata sebesar 2,88. Hal tersebut menunjukkan bahwa tingginya kepuasan ekstrinsik pegawai di RSIA NUN Surabaya adalah karena pegawai di RSIA NUN Surabaya memiliki kesempatan untuk berkembang. Kepuasan dan ketidakpuasan kerja karyawan bergantung terhadap keadilan yang dirasakan oleh pegawai. Keadilan tersebut terdiri dari tiga komponen yaitu input, proses, dan output yang salah satuya adalah kesempatan untuk berprestasi dan berkembang 9 Oleh karena itu, penting bagi rumah sakit untuk memberikan kesempatan kepada pegawai rumah sakit untuk berprestasi dan mengembangkan diri, karena hal tersebut tidak hanya berdampak bagi karyawan namun juga berdampak pada kemajuan rumah sakit.

Penilaian terendah pegawai di RSIA NUN Surabaya tentang kepuasan ekstrinsik pegawai adalah pada pernyataan "gaji yang diterima dengan jumlah pekerjaan" dengan rerata sebesar 2,35. Hasil tersebut menunjukkan bahwa rendahnya kepuasan kerja ekstrinsik pegawai di RSIA NUN Surabaya dikarena pegawai merasa gaji yang diterima belum sesuain dengan pekerjaan yang dilakukan. Kepuasan kerja karyawan akan bergantung pada perbedaan apa yang seharusnya ada (harapan, kebutuhan, nilai) dengan apa yang menurut perasaan atau persepsi yang telah diperoleh atau dicapainya. Bila yang didapat ternyata lebih besar dari yang diinginkan maka orang akan menjadi puas walaupun terdapat discrepancy, hal ini disebut positive discrepancy. Sebaliknya jika kenyataan yang didapatkan jauh dibawah batas minimum yang diinginkan maka akan terjadi ketidakpuasan, hal ini disebut negative discrepancy. Pegawai di RSIA NUN memiliki kepuasan ekstrinsik sedang dikarenakan pegawai merasa gaji yang diterima belum sesuai dengan pekerjaan yang dilakukan. Hal tersebut mengakibatkan terjadinya negative discrepancy yaitu kondisi ketidakpuasan karena kenyataan yang didapatkan berada dibawah kenginan karyawan ${ }^{9}$

\section{Kepuasan Umum}

Kepuasan umum adalah perasaan senang atau tidak senang yang merupakan hasil dari persepsi pengalaman pegawai selama masa kerjanya terhadap lingkungan kerja. Hasil kepuasan kerja jika dilihat berdasarkan indikator kepuasan umum menunjukkan bahwa sebagian besar pegawai (60\%) memiliki kepuasan kerja umum dengan kategori sangat baik. Hal tersebut menunjukkan bahwa sebagian besar pegawai di RSIA NUN Surabaya merasa puas dengan lingkungan tempat kerja mereka.

Penilaian pegawai di RSIA NUN Surabaya pada aspek kepuasan umum, penilaian tertinggi adalah pada pernyataan "hubungan dengan rekan kerja" dengan rerata 3,08. Hal tersebut menunjukkan bahwa tingginya kepuasan umum pegawai di RSIA NUN Surabaya dikarenakan terdapat hubungan baik antara pegawai dengan rekan kerjanya. Penilaian terendah pegawai terhadap kepuasan 
umum adalah pada pernyataan "kondisi lingkungan kerja" dengan rerata sebesar 2,95. Hal tersebut menunjukkan bahwa rendahnya kepuasan umum pegawai di RSIA NUN Surabaya terjadi karena kurang puasnya pegawai tehadap kondisi lingkungan kerja.

Lingkungan kerja adalah adalah tempat seorang karyawan dalam menyelesaikan pekerjaan, baik lingkungan fisik dan nonfisik. Lingkungan kerja dapat mempengaruhi semangat dalam melaksanakan pekerjaan Lingkungan kerja meliputi perlengkapan atau fasilitas kerja, lingkungan tempat kerja, dan suasana kerja. ${ }^{10}$ Lingkungan Kerja juga berpengaruh terhadap kepuasan kerja ${ }^{11}$. Oleh karena itu, penting bagi manajeman untuk menyediakan lingkungan kerja yang kondusif dan mendukung karyawan dalam melakukan pekerjaan.

Faktor rekan kerja (co-worker), gaya penyeliaan (quality and technical support), kondisi lingkungan fisik kerja (psychological working condition), kebijakan perusahaan (company policies), gaji (salary), dan keamanan kerja (job security). Faktor tersebut menjadi daya dorong yang datang dari luar diri seseorang, terutama dari organisasi tempatnya bekerja atau faktor yang berhubungan dengan ketidakpuasan kerja dan merupakan suatu faktor ekstrinsik yang berkaitan dengan pekerjaan. Jika faktor ini dirasakan kurang atau tidak diberikan, maka karyawan akan merasa tidak puas (dissatisfied). Faktor ini disebut hygiene karena faktor tersebut menggambarkan lingkungan karyawan dan melayani fungsi utama dari pencegahan ketidakpuasan kerja. ${ }^{1}$

Berdasarkan hasil penelitian kepuasan kerja dilihat melalui kepuasan intrinsik, kepuasan ekstrinsik, dan kepuasan umum. Untuk memperkuat dan meningkatkan kepuasan kerja dibutuhkan penguatan system manajemen sumberdaya manusia yang mendorong kebutuhan psikologi karyawan dan membentuk lingkugan kerja yang kondusif. Berdasarkan hasil penelitian diketahui bahwa sebagian besar (66.7\%) kepuasan kerja pegawai secara keseluruahan berada pada kategori baik. Hal tersebut menunjukkan bahwa sebagian besar pegawai memiliki kepuasan yang baik terhadap kondisi di tempat kerja baik secara intrinsik, ekstrinsik, maupun umum.

Kepuasan kerja tergantung pada perbedaan (discrepancy) antara apa yang seharusnya ada (harapan, kebutuhan, nilai) dengan apa yang menurut perasaan atau persepsinya telah diperoleh atau dicapai melalui pekerjaan. kepuasan dan ketidakpuasan yang dirasakan seseorang tergantung dari apakah ia merasakan adanya keadilan (equity) atau tidak. Perasaan tersebut diperoleh dengan cara membandingkan dirinya dengan orang lain yang setingkat, sekantor ataupun ditempat lain. Keadilan (equity) adalah suatu keadaan yang muncul dalam pikiran seseorang, jika ia merasa bahwa rasio antara usaha dan imbalan adalah seimbang dengan rasio individu yang dibandingkannya ${ }^{6}$

Sebagian besar karyawan $(66,7 \%)$ di RSIA NUN Surabaya memiliki kepuasan kerja dengan kategori baik. Hal tersebut menunjukkan bahwa karyawan merasa harapan karyawan terkait dengan pengelolaan sumberdaya manusa di RSIA NUN Surabaya sudah sesuai dengan kenyataan yang diberikan oleh rumah sakit. Dasar kepuasan kerja adalah derajat keadilan yang diterima pegawai dalam situasi kerjanya, semakin adil derajat keadilan yang diterima pegawai, maka akan semakin puas pegawai yang bersangkutan. ${ }^{6}$

Terdapat tiga elemen untuk mencapai equity atau kondisi seseorang merasa harapan terkait dengan pekerjaan sesuai dengan kenyataan yaitu: input, out come, comparison persons (orang pembanding) dan adanya situasi equity-unequity. Input adalah segala sesuatu yang berharga yang dirasakan pegawai sebagai hasil dari sumbangan terhadap pekerjaannya misalnya pendidikan, pengalaman, keterampilan, besarnya usaha yang dilakukan, jam kerja, dan sebagainya. Outcome adalah segala sesuatu yang berharga yang diterima pegawai sebagai hasil dari pekerjaannya seperti gaji, simbol status, 
kesempatan berprestasi, pengakuan. ${ }^{9}$ Oleh karena itu, untuk mencapai kepuasan kerja yang baik, maka karyawan harus berada dalam kondisi equity. Dimana karyawan harus merasakan outcome yang diberikan oleh manajemen rumah sakit sesuai dengan harapan karyawan. Sehinga untuk mempertahankan dan meningkatkan kepuasan kerja karyawan manajemen harus memberikan output yang sesuai dengan harapan karyawan.

Menurut para ahli, keberhasilan organisasi dalam mengelola sumber daya manusia diindikasikan dengan adanya kepuasan kerja dari para karyawan, meningkatnya kinerja karyawan, dan tercapainya tujuan organisasi. Organisasi yang memiliki jumlah pegawai dengan kepuasan kerja tinggi cenderung lebih efektif bila dibandingkan dengan organisasi yang memiliki jumlah pegawai dengan kepuasan kerja yang sedikit. Karena pelayanan maksimal dari karyawan terhadap perusahaan tergantung dari yang dirasakan karyawan terhadap pekerjaan, rekan kerja, dan supervisor. ${ }^{12}$

Kepuasan kerja dapat berpengaruh terhadap keinginan karyawan untuk meninggalkan pekerjaannya. ${ }^{13}$ Ketidakpuasan kerja dapat menyebabkan beberapa hal antara lain exit, voice, loyalty, dan neglect. Oleh karena itu penting bagi organisasi untuk meningkatkan kepuasan kerja karyawan. Karena kepuasan dan sikap karyawan merupakan sikap penting dalam menentukan tingkah laku dan respon terhadap pekerjaan sehingga efektivitas organisasi tercapai. Terdapat beberapa faktor yang mempengaruhi kepuasan kerja antara lain, pemenuhan kebutuhan, perbedaan harapan antara pegawai dengan organisasi, pencapaian nilai, keadilan, dan komponen genetik. ${ }^{15}$

Tabel 2.Penilaian Kepuasan Kerja

\begin{tabular}{clrrrr}
\hline No & Perrnyataan & Min & Max & Mean & SD \\
\hline Kepuasan Intrinsik & & & & \\
\hline 1 & $\begin{array}{l}\text { Kesibukan } \\
\text { kegiatan } \\
\text { pekerjaan. }\end{array}$ & 2 & 4 & 2,96 & 0,52 \\
\hline 2 & Kesempatan & 2 & 4 & 2,98 & 0,45 \\
\hline
\end{tabular}

\begin{tabular}{|c|c|c|c|c|c|}
\hline & $\begin{array}{l}\text { yang diberikan } \\
\text { untuk } \\
\text { melakukan } \\
\text { beragam } \\
\text { pekerjaan. }\end{array}$ & & & & \\
\hline 3 & $\begin{array}{l}\text { Kesempatan } \\
\text { menjadi } \\
\text { "seseorang" di } \\
\text { dalam } \\
\text { lingkungan } \\
\text { kerja. }\end{array}$ & 2 & 4 & 2,98 & 0,26 \\
\hline 4 & $\begin{array}{l}\text { Pekerjaan tidak } \\
\text { bertentangan } \\
\text { dengan hati } \\
\text { nurani. }\end{array}$ & 2 & 4 & 3,00 & 0,52 \\
\hline 5 & $\begin{array}{l}\text { Kestabilan } \\
\text { status } \\
\text { pekerjaan. }\end{array}$ & 2 & 4 & 2,93 & 0,45 \\
\hline 6 & $\begin{array}{l}\text { Kesempatan } \\
\text { melakukan } \\
\text { sesuatu untuk } \\
\text { orang lain } \\
\text { berkaitan } \\
\text { pekerjaan. }\end{array}$ & 2 & 4 & 3,00 & 0,30 \\
\hline 7 & $\begin{array}{l}\text { Kesempatan } \\
\text { menggunakan } \\
\text { kemampuan } \\
\text { dalam } \\
\text { pekerjaan. }\end{array}$ & 2 & 4 & 2,98 & 0,34 \\
\hline 8 & $\begin{array}{l}\text { Kebebasan } \\
\text { menggunakan } \\
\text { penilaian } \\
\text { terhadap diri } \\
\text { sendiri. }\end{array}$ & 2 & 4 & 3,04 & 0,37 \\
\hline 9 & $\begin{array}{l}\text { Kesempatan } \\
\text { atau kebebasan } \\
\text { berkreativitas }\end{array}$ & 2 & 4 & 2,93 & 0,50 \\
\hline 10 & $\begin{array}{l}\text { Pencapaian } \\
\text { terhadap } \\
\text { prestasi kerja }\end{array}$ & 1 & 4 & 2,82 & 0,58 \\
\hline 11 & $\begin{array}{l}\text { Kesempatan } \\
\text { menggunakan } \\
\text { wewenang }\end{array}$ & 1 & 4 & 2,87 & 0,40 \\
\hline 12 & $\begin{array}{l}\text { Kesempatan } \\
\text { untuk bekerja } \\
\text { secara mandiri. }\end{array}$ & 2 & 4 & 2,96 & 0,30 \\
\hline \multicolumn{6}{|c|}{ Kepuasan Ekstrinsik } \\
\hline 13 & $\begin{array}{l}\text { Cara atasan } \\
\text { menangani } \\
\text { keluhan }\end{array}$ & 1 & 4 & 2,71 & 0,63 \\
\hline 14 & $\begin{array}{l}\text { Kebijakan } \\
\text { (aturan) yang } \\
\text { diterapkan. }\end{array}$ & 2 & 4 & 2,69 & 0,51 \\
\hline 15 & $\begin{array}{l}\text { Pengawasan } \\
\text { atasan } \\
\text { mengenai hal } \\
\text { teknis. }\end{array}$ & 2 & 4 & 2,64 & 0,53 \\
\hline 16 & $\begin{array}{l}\text { Gaji yang } \\
\text { diterima } \\
\text { dengan jumlah } \\
\text { pekerjaan }\end{array}$ & 1 & 4 & 2,36 & 0,71 \\
\hline 17 & $\begin{array}{l}\text { Kesempatan } \\
\text { untuk } \\
\text { berkembang }\end{array}$ & 2 & 4 & 2,89 & 0,38 \\
\hline 18 & Pujian atasan & 1 & 4 & 2,71 & 0,66 \\
\hline
\end{tabular}




\begin{tabular}{clllll}
\hline \multicolumn{6}{c}{$\begin{array}{l}\text { terhadap } \\
\text { pekerjaan }\end{array}$} \\
\hline Kepuasan Umum & & & & & \\
\hline 19 & $\begin{array}{l}\text { Hubungan } \\
\text { dengan rekan } \\
\text { kerja. }\end{array}$ & 3 & 4 & 3,09 & 0,29 \\
\hline 20 & $\begin{array}{l}\text { Kondisi } \\
\text { lingkungan } \\
\text { kerja }\end{array}$ & 1 & 4 & 2,62 & 0,81 \\
\hline
\end{tabular}

\section{SIMPULAN DAN SARAN}

Kepuasan pegawai di RSIA NUN Surabaya menunjukkan bahwa sebagian besar $(66.7 \%)$ kepuasan kerja pegawai secara keseluruhan berada pada kategori baik. Hal tersebut menunjukkan bahwa sebagian besar pegawai memiliki kepuasan kerja yang baik terkait dengan pengelolaan sumberdaya manusia. Namun terdapat beberapa hal yang perlu diperhatikan oleh manajemen rumah sakit antara lain kepuasan karyawan terkait pencapaian terhadap prestasi kerja, gaji karyawan, dan kondisi lingkungan kerja karena ketiga elemen tersebut memiliki nilai yang lebih rendah dibandingkan dengan elemen yang lain. Sehingga penting bagi rumah sakit untuk mendorong karyawan untuk meningkatkan prestasi kerja dengan memberikan kesempatan karyawan untuk mengembangkan diri melalui kegiatan pendidikan dan pelatihan.Serta melakukan telaah terhadap gaji yang diberikan dan menyediakan lingkungan kerja yang kondusif sehingga dapat meningkatkan kepuasan kerja karyawan.

Saran bagi penelitian selanjutnya adalah menganalisis pengaruh kepuasan kerja dengan beberapa variabel lain seperti turnover intention, dan kinerja karyawan di rumah sakit.

\section{UCAPAN TERIMA KASIH}

Peneliti mengucapkan terimakasih kepada RSIA NUN Surabaya sebagai tempat penelitian,

peneliti juga berterima kasih kepada semua pihak yang telah membantu terelesaikannya artikel ini.

\section{REFERENSI}

1. Robbins S. Perilaku Organisasi. Jakarta: Salemba; 2006.

2. Toly AA. Analisis faktor-faktor yang mempengaruhi turnover intentions pada staf kantor akuntan publik. Jurnal Akuntansi dan Keuangan. 2004 Jun 14;3(2):102-25

3. Malthis L. Manajemen Sumberdaya Manusia. Jakarta: Salemba Empat; 2009.

4. Griffeth RW, Hom PW, Gaertner S. A metaanalysis of antecedents and correlates of employee turnover: Update, moderator tests, and research implications for the next millennium. Journal of management. 2000 Jun;26(3):463-88.

5. Hoboubi N, Choobineh A, Ghanavati FK, Keshavarzi S, Hosseini AA. The impact of job stress and job satisfaction on workforce productivity in an Iranian petrochemical industry. Safety and health at work. 2017 Mar 1;8(1):67-71.

6. Handoko, T. Manajemen Personalia dan Sumberdaya Manusia. Yogyakarta: BPFE; 2000.

7. Robbins S, Judge. Perilaku Organisasi. Jakarta: Salemba Empat; 2008.

8. Lugestin SS. Pengaruh Faktor Kepuasan Kerja Intrinsik Dan Ekstrinsik Terhadap Intention To Quit Pada Karyawan Pt. Rimo Departemen Store Cabang Plaza Tunjungan I Surabaya (Doctoral Dissertation, Universitas Airlangga)

9. Wexley, Yukl. Perilaku Organisasi dan Psikologi Personil. Jakarta: Rineka Cipta: 1997.

10. Sarwoto. Manajemen Sumberdaya Manusia. Jakarta; Penerbit Bumi Aksara: 2001.

11. Suryalena S, Murtafia I. Hubungan Lingkungan Kerja dengan Kepuasan Kerja Karyawan (Kasus Bagian Pengolahan PT. Surya Bratasena Plantation Kecamatan Pangkalan Kuras Kabupaten Pelalawan). Jurnal Online Mahasiswa Fakultas Ilmu Sosial dan Ilmu Politik Universitas Riau. 2015;2(2).

12. Ostroff C. The relationship between satisfaction, attitudes, and performance: An organizational level analysis. Journal of applied psychology. 1992 Dec;77(6):963.

13. Kartika RC. Upaya Menurunkan Turnover 
ARTERI : Jurnal Ilmu Kesehatan

Vol.1, No. 1, Nopember 2019, hlm. 115-122

Melalui Peningkatan Kepuasan Kerja Pegawai di Rumah Sakit. Jurnal Manajemen Kesehatan Yayasan RS. Dr. Soetomo. 2018 May 15;4(1):17.

14. Soeprijadhie AJ. Faktor-faktor Kepuasan Kerja Pengaruhnya terhadap Kinerja Karyawan di Radio Republik Indonesia Manado. Jurnal EMBA: Jurnal Riset Ekonomi, Manajemen, Bisnis dgtan Akuntansi. 2013 Sep 9;1(4). 